\title{
An Exploratory Study of HBCU Accounting and Other Business Students' Perceptions and Usage of LinkedIn
}

\author{
Xia Zhang ${ }^{1} \&$ Botao Chen ${ }^{2}$ \\ ${ }^{1}$ College of Business and Public Affairs, Alabama A\&M University, 4900 Meridian St. N., Normal, AL, 35762, \\ U.S.A. \\ ${ }^{2}$ School of Business and Technology, University of Maryland Eastern Shore, 11868 College Backbone Rd., Princess \\ Anne, MD 21853, U.S.A. \\ Correspondence: Xia Zhang, Department of Accounting \& Finance, College of Business \& Public Affairs, Alabama \\ A\&M University, Normal, AL, 35762, U.S.A. Tel: 1-256-372-4786. E-mail: xia.zhang@aamu.edu
}

Received: November 1, 2018

Accepted: December 18, 2018

Online Published: December 28, 2018

doi:10.5430/afr.v8n1p77

URL: https://doi.org/10.5430/afr.v8n1p77

\begin{abstract}
We administer a survey to evaluate accounting and other business students' perceptions and usage of the social networking site LinkedIn. The participants are students at historically black colleges and universities (HBCUs), who are underrepresented groups. Our research examines how LinkedIn shapes their social identity and establishes their self-presentation in a world of social networking. It also examines how students' perceptions of LinkedIn benefit their future career development as well as interactive learning. The results of the survey reveal that LinkedIn is an invaluable social media tool for college students to present their social identity, network with professionals as a helpful source of career and job information. However, compared with business students, accounting students put less trust in the information obtained via professional communities on LinkedIn. Accounting students agree that LinkedIn is more distracting than helpful to students for academic work. Our study has strong implications for accounting students and other business students, as well as educators in HBCU settings.
\end{abstract}

Keywords: HBCUs, accounting students, LinkedIn, social networking site, social identity, career development

\section{Introduction}

With the increasingly developed emerging technology and the internet, social networking sites connect people from all over the world. People start to actively participate in "social networks" to connect, share information, and express their ideas. Social networking sites, such as LinkedIn, Facebook, Twitter, and YouTube, have become a primary mode of societal interaction (Roldan, Sutanonpaiboon, \& Burkhard 2017). According to eBizMBA Rank in May 2018, LinkedIn is one of the top five most popular social networking sites in terms of estimated unique monthly visitors (EBizMBA 2018). It has been praised for its usefulness in fostering business relationships. LinkedIn is the most advantageous social networking tool available to job seekers and business professionals today (Foss 2012; Heifetz 2015; Beach 2016). Social networking sites are popular among students, helping students to interact with one another, share ideas, and improve their creativity.

A considerable amount of literature is devoted to investigating the effects, motivations, and outcomes of social networking sites on different disciplines such as psychology, information technology, and sociology. The dimensions on which the previous studies examine the effects of social networking sites can be classified as follows: 1) social identity (e.g., Boyd \& Heer 2006; Ellison, Steinfield, \& Lampe 2007; Pempek, Yermolayeva, \& Calvert 2009); 2) future career development (e.g., Hannon 2015; Heifetz 2015; Beach 2016; Escobedo 2017); and 3) academic performance (e.g., Mazer, Murphy, \& Simonds 2007; Chu \& Meulemans 2008; Gabre \& Kumar 2012; Irwin, Ball, \& Desbrwo 2012; McCorkle \& McCorkle 2012; Mendez, Le, \& Cruz 2012; Paul, Baker, \& Cochran 2012; Stone, Fiedler, \& Kandunias 2014).

However, the previous studies of social networking sites primarily focus on Facebook and Twitter (e.g., Dwyer 2007; Ellison et al. 2007; Pempek et al. 2009; Hew 2011; Iwin et al. 2012; Paul, Baker, \& Cochran 2012, and Mathiyalakan, Heilman, White, \& Brusa 2016). Only a few studies examine the impact of the professional social networking site LinkedIn. For instance, Parez (2013) investigates the ethical practices of LinkedIn recruitment. McCorkle \& McCorkle (2012) address the use of LinkedIn in the marketing classroom as a means of developing social networking skills and 
other supporting skills such as communication and creativity. Florenthal (2015) collects data from 30 upper-level, undergraduate business students and finds that career development is more gratifying, compared with interpersonal communication, online identity, and information for LinkedIn users instead of the users of Facebook, MySpace, and Bebo.

Our study complements the prior literature to evaluate the perceptions and usage of LinkedIn by accounting and other business students at historically black colleges and universities (HBCUs). Our research provides empirical evidence for the impact of LinkedIn on HBCU business students and especially accounting students. The participants are HBCU accounting and non-accounting business students. Among $102 \mathrm{HBCU}$ schools in U.S.A., at least 66 offer accounting degree programs. HBCUs are major providers of African American accountants and auditors in accounting industries. The National Association of Black Accountants (NABA, Inc.) represents over 200,000 African American professionals in accounting, finance, and related business professionals. However, because African American students are underrepresented groups, limited research is conducted regarding their perceptions and usage of social media (Gabre \& Kumar 2012; Junco 2013). In fact, some prior literature indicates that African American students use social media in a different way compared with other groups. Gabre \& Kumar (2012) find that African American accounting students are more likely to report higher stress scores than their non-African American counterparts. African American students use Facebook less for academics when compared to Hispanic students (Mathiyalakan et al. 2016).

To our knowledge, little academic literature has empirically examined the effect of LinkedIn on HBCU students. Our study provides an exploratory investigation of perceptions and usage of LinkedIn by business students, especially accounting students at HBCUs. The questions addressed include: why accounting and business students use LinkedIn, how they interact through LinkedIn, what their time commitment is, and how the nature of the influence affects the development of identity and communication, as well as what the benefits are for career development. The study employs social capital theory and motivation theory to address how LinkedIn influences accounting students and other business students in three dimensions: social identity, future career development, and as an interactive learning resource.

The findings reveal that both accounting and other business students at HBCUs trust the information on LinkedIn and would be willing to respond and share information with the communities on LinkedIn. The respondents are willing to present themselves favorably on the profiles of LinkedIn. The respondents view LinkedIn as a helpful source of career information and a platform to connect with their alumni in future career development. However, when compared with other business students, accounting students perceive that other LinkedIn members are less open and less receptive to the needs of each other's. Thus, they are less likely to get up-to-date information about jobs and careers. In terms of perception of interactive learning resources of LinkedIn, accounting students show less trust in the information obtained via professional communities on LinkedIn. They agree that LinkedIn is more distracting than helpful to students for their academic work.

Our study has practical implications for accounting practitioners and accounting professionals. The findings have strong implications for accounting students, accounting and business professionals, especially those at HBCUs. The previously mentioned groups will benefit from the impact of LinkedIn in their life and career so that they can utilize this social media platform more effectively and efficiently. The study also benefits educators at colleges, who can provide appropriate education and training for business students to utilize the social networking sites such as LinkedIn to benefit society.

The remainder of this paper is organized as follows. Section II provides a review of the literature and hypotheses related to the impact of LinkedIn on accounting students and other business students. Section III addresses methodology. Section IV describes the findings of our study. Section V presents conclusions, implications, and limitations.

\section{Literature Review}

\subsection{Background}

LinkedIn is a social networking site for business people and professionals. Founded in December 2002 and launched on May 5, 2003, LinkedIn operates the world's largest professional network on the Internet with over half a billion members in over 200 countries and territories. LinkedIn is created to share professional information related to career, jobs, education and other skills. LinkedIn allows users to join groups, apply for jobs, post their business references, and search for any type of business contact. Previous research has shown that LinkedIn, as a professional social networking site, represents not only a powerful tool to interact with other professionals, but is also a platform for building personal images for individuals working in different businesses (DamnjanovIé, Matovic, Kostic, \& Okanovieé 2012). 
LinkedIn is a platform for accounting professionals to connect with each other. Since 2012, The American Institute of Certified Public Accountants (AICPA) partnered with Telligent to create a social networking site - This Way to CPA for college students who aspire to become accountants. AICPA integrates its community website with social networking sites such as LinkedIn to ensure that members know how and where to stay involved with AICPA. Johnson (2011) shows that LinkedIn can help accounting firms enhance their business development with LinkedIn. In fact, large professional-service firms such as Ernst \& Young, Deloitte, PricewaterhouseCoopers, and KPMG have already used social network sites such as LinkedIn for recruiting purposes (Herbold \& Douma 2013).

\subsection{LinkedIn as a Social Networking Site for Enhancement of Social Capital}

Similar to other social networking sites, LinkedIn makes it easy for people to maintain their social networks and to enhance their social capital (Utz 2016). Social capital refers to the resources accumulated through the relations among people (Coleman 1988; Ellison et al. 2007). Social capital can be defined as the benefits one receives from one's relationship with other people. As an investment in social relations by individuals, through social capital, they gain access to embedded resources to enhance expected returns of instrumental or expressive actions (Lin 1999). Social capital can be accessed through the relationships among people over social networking sites such as Facebook, Twitter, and LinkedIn (Lu \& Yang 2014).

A large number of prior studies focus on social capital gained from use of social networking sites (e.g., Morris, Teevan, \& Panovich 2010; Vitak \& Ellison 2012; Ellison et al. 2007; Gray, Ellison, \& Vitak 2013; Liu \& Yu, 2013; Burt 1999; Adler \& Kwon 2002; Utz 2016). These studies reveal that people do get useful recommendations from their Facebook contacts (Morris et al. 2010; Vitak \& Ellison, 2012; Ellison et al. 2011; Gray et al. 2013; Liu \& Yu, 2013). Generally, social capital is associated with positive diverse outcomes such as career advancement (Burt 1999), organizational success (Nahapiet \& Ghoshal 1998), and other positive social outcomes (Adler \& Kwon 2002). Utz (2016) uses a social capital framework to examine whether and how a sample of Dutch online users get professional informational benefits from the use of three types of social networking sites (LinkedIn, Twitter, Facebook). The results show that users of LinkedIn and Twitter report higher informational benefits than non-users, whereas Facebook users report lower informational benefits.

For youth who are striving to establish their identity as young adults, social networking sites offer many benefits to strengthen social relationships (Ellison et al. 2007). Recent studies examine Facebook use among college students, indicating that there is a link between use of the service and the students' social capital (e.g., Ellison et al. 2007; Johnston, Tanner, Lalla, \& Kawalski 2013; Steinfield, Ellison, \& Lampe 2008; Florenthal 2015). For instance, Ellison et al. (2007) suggests that intensive Facebook use is closely related to the formation and maintenance of social capital. Facebook primarily focuses on facilitating personal self-presentation, while LinkeIn caters toward users' self-promotion (Dijck 2013).

\subsection{LinkedIn and Motivation Theory}

As a social networking site, LinkedIn has penetrated rapidly into people's lives. It is an important platform of interaction and involvement for users to obtain personal benefits and social effects (Lin \& Lu 2011). Some prior studies investigate the behaviors of social networking site users from a motivation perspective (e.g., Davis, Bagozzi, \& Warshaw 1992; Igbaria, Parsuraman, \& Baroudi 1996; Van Der Heijden 2004; Lin \& Bhattacherjee 2008; and Lin \& $\mathrm{Lu}$ 2011). According to Reiss (2012), psychologists divide motivations into two types: intrinsic and extrinsic.

In terms of extrinsic motivations for people to use a social networking site, Kwon \& Wen (2010) find that people's perceived usefulness of a social networking site affects their positive intention to use the networking site. Social networking sites allow users to become acquainted with each other. A user of social networking sites is more concerned with whether the social networking site allows him/her to effectively build and maintain relationships. (Lin \& Lu 2011). As a business social networking site, LinkedIn attracts more and more professionals including college students. LinkedIn provides an opportunity for marketing and business students for personal job search and career development (McCorkle \& McCorkle 2012). Furthermore, use of LinkedIn can foster the development of social networking skills for the purpose of personal branding (McCorkle \& McCorkle 2012).

Consistent with social capital theory, the intrinsic motivation to drive users to use a social networking site lies in the direct benefit from posting content leading to "the doing of an activity for its inherent satisfactions rather than for some separable consequence" (Ryan \& Deci 2000, 71). Social networking sites enable users to express their identity and build self-image. In detail, social networking sites enable users to post information on their personal page (i.e., profile), to build self-image, and to view peer or group opinions. In terms of a business-oriented social networking site, 
LinkedIn allows users to create a profile based on their professional affiliations and connect with professional contacts within and outside their professional networks.

\subsection{Hypotheses}

Based on social capital theory and motivation theory, LinkedIn, as a professional social networking site, not only shapes the way college students construct their social and professional identities, but also provides them with professional informational benefits. First of all, LinkedIn provides a platform for young adults to establish and strengthen their social identity (Ellison et al. 2007; Alexander 2013). Following Ellison et al. (2007) which examine the relationship between usage of Facebook and the formation and maintenance of social capital, we propose the following hypotheses with respect to the impact of LinkedIn:

\section{H1: Accounting and other business students perceive LinkedIn as positive social capital to construct their social and professional identity.}

Moreover, previous studies (Benson et al., 2014; Starcic et al., 2017) have shown that LinkedIn has progressively been utilized for e-recruitment. Utz (2016) finds that LinkedIn provides a platform for users to obtain professional informational benefits, e.g. career opportunities. Therefore, the second hypothesis is proposed as follows:

\section{H2: Accounting and other business students perceive LinkedIn as a positive benefit to their future career development.}

Finally, various prior studies examine the effects of social networking sites on college students' academic performance as a learning resource. Junco (2011) states that social networking sites can serve important educational purposes and increase student engagement in higher education given their high popularity. Buzzetto-More (2012) uses a survey to evaluate management students' perceptions of using Facebook at a U.S. Mid-Atlantic minority-serving university and finds that the learners consider Facebook a valuable tool that helps to strengthen interpersonal relationships, build learning communities, and engage students. Accordingly, we make the following hypothesis regarding the users' perceptions of LinkedIn:

H3: Accounting and other business students believe LinkedIn is a positive interactive learning resource in the university setting.

\section{Methodology}

\subsection{Survey Instrument}

We collect data by conducting a survey among undergraduate and graduate accounting students and other business students at three top 25 HBCUs in both the southern U.S. and northern U.S. The survey includes three parts: A) User Experience on LinkedIn; B) LinkedIn Users' Usage and Acceptance, and C) Demographic Information. Part A presents four questions in four dimensions: Time Length as a LinkedIn User; Frequency of Using LinkedIn; LinkedIn Connections; Purpose of Using LinkedIn. Part B presents 16 agree/disagree questions in terms of three dimensions: Social and Professional Identity (5 questions); Future Career Development (6 questions), and Interactive Learning Resources (5 questions). Part C includes different demographic information such as Gender, Race, Classification, Age, Home Residence, and Major.

Our survey instrument is created based on a series of relevant academic journals and practitioner journals. The questions in three dimensions: social and professional identity; future career development; and Interactive Learning Resources are adapted with reference to the previous studies respectively (Ellison et al. 2007, Singson \& Sunkara 2012; Herbold \& Douma 2013, Chiang \& Suen 2015; Dwyer, Hiltz, \& Passerini 2007, and Utz 2016). The sixteen survey questions on three dimensions are measured on a five-point Likert scale, with $1=$ Strongly Disagree $(\mathrm{SD}), 2=$ Disagree (D), $3=$ Neither Agree and Disagree (N), $4=$ Agree (A), and $5=$ Strongly Agree (SA).

\subsection{Participants}

The participants in our study are students from the classes of College of Business at three HBCUs in the U.S. including the undergraduate accounting classes, the graduate auditing class, the graduate management class, the MBA accounting class, and one Ph. D class of different business disciplines. We ask 93 students who have LinkedIn accounts to complete the survey. Among the 93 respondents whose surveys are usable, 48 are accounting majors and 45 are business non-accounting majors.

\subsection{Statistical Approach}

Our study employs descriptive statistics to describe the frequency distributions of the perceptions and usage of LinkedIn by accounting and other business students. We also use the chi-squared test to compare the differences of 
distributions between these two groups.

\section{Findings}

\subsection{Descriptive Analysis - Users' Experience of LinkedIn}

Four questions describing Users' Experience of LinkedIn are presented in Table 1 and Figure 1. Question 1 is as follows: "How long have you been a LinkedIn user? (Time)." For accounting majors, about $45 \%$ of the respondents have above two years' experience of using LinkedIn. For business non-accounting majors, about $48 \%$ of the respondents have above two years' experience of using LinkedIn. Question 2 is as follows: "On average, how often do you check LinkedIn? (Frequency)." For accounting majors, 76.6\% of the respondents check LinkedIn "at least once a month." For business non-accounting majors, about $67.4 \%$ of the respondents check LinkedIn "at least once a month."

Table 1. Results of Users Experience on LinkedIn

\begin{tabular}{lcc}
\hline \multicolumn{1}{c}{ Questions } & $\begin{array}{c}\text { Accounting } \\
\text { Major }\end{array}$ & $\begin{array}{c}\text { Non-Accounting } \\
\text { Major }\end{array}$ \\
\hline 1. How long have you been a LinkedIn user? (Time) & & \\
a. < 1 year & $25.5 \%$ & $27.9 \%$ \\
b. 1-2 years & $29.8 \%$ & $23.3 \%$ \\
c. 2-3 years & $19.1 \%$ & $27.9 \%$ \\
d. 3-4 years & $10.6 \%$ & $16.3 \%$ \\
e. 4-5 years & $8.5 \%$ & $2.3 \%$ \\
f. > 5 years & $6.4 \%$ & $2.3 \%$ \\
2. On average, how often do you check LinkedIn? (Frequency) & & \\
a. At least once a day & $19.1 \%$ & $11.6 \%$ \\
b. At least once a week & $21.3 \%$ & $16.3 \%$ \\
c. At least once a month & $36.2 \%$ & $39.5 \%$ \\
d. Once every 2-3 months & $23.4 \%$ & $32.6 \%$ \\
3. How many LinkedIn "Connections" do you have? (Connection) & & \\
a. None & $15.2 \%$ & $4.7 \%$ \\
b. Up to 10 & $39.1 \%$ & $46.5 \%$ \\
c. 11-50 & $32.6 \%$ & $30.2 \%$ \\
d. 51+ & $13.0 \%$ & $18.6 \%$ \\
4. What do you mostly use LinkedIn for? (Purpose) & & \\
a. It is a relevant, active and interesting community & $6.6 \%$ & $8.9 \%$ \\
b. It will let me stay up-to-date with the news/updates & $6.6 \%$ & $8.9 \%$ \\
c. I believe this will help me to get new useful connections & $24.6 \%$ & $3.9 \%$ \\
d. Check out how your connections are doing (photos, walls etc.) & $3.3 \%$ & $8.2 \%$ \\
e. Update your profile to pass time & $50.8 \%$ & \\
f. It will be helpful for job searching and career development & & \\
\hline & & \\
\hline
\end{tabular}




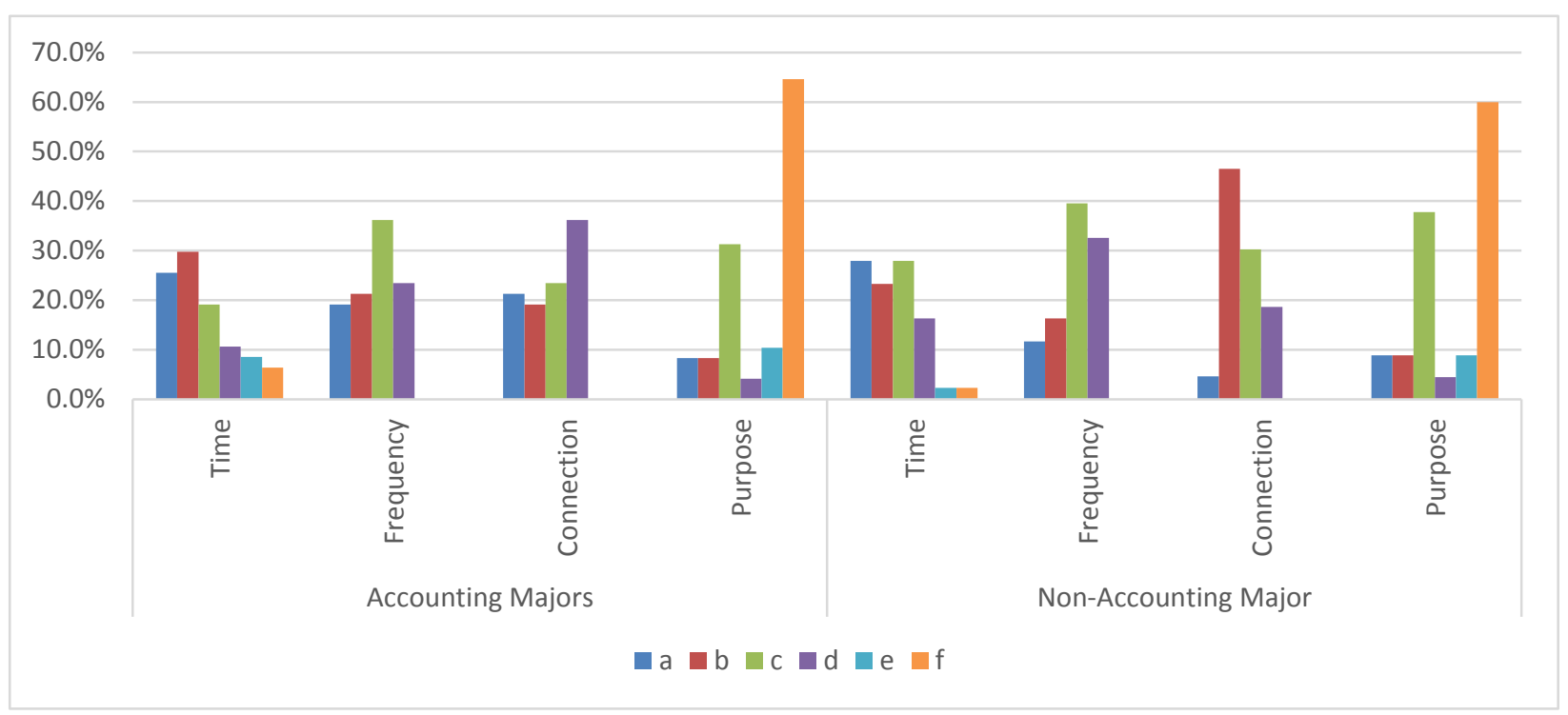

Figure 1. Users Experience

Question 3 is as follows: "How many LinkedIn 'Connections' do you have?" For accounting majors, about $46 \%$ of the respondents have " 11 to 50 connections" or " $51+$ connections." For business non-accounting majors, about $49 \%$ of the respondents have "11 to 50 connections" or "51+ connections." Question 4 presents the following: "What do you mostly use LinkedIn for? (Purpose)." Among the six answer choices, two are worth mentioning here. For the answer "I believe this will help me to get new useful connections", about $25 \%$ of accounting majors and around $38 \%$ of business non-accounting majors believe so. For the answer "It will be helpful for job search and career development", about 51\% of accounting majors and $60 \%$ of business non-accounting majors believe so.

In terms of Usage of LinkedIn, the results of the chi-squared test indicate there are no significant differences between the above two groups at all dimensions. In summary, the results indicate that nearly $50 \%$ accounting or other business students have over two years' experience using LinkedIn and have built over 10 connections. They tend to be active participant in LinkedIn (at least once a month) because they believe LinkedIn will help them to build new connections and promote their job search and career development.

\subsection{H1: Social and Professional Identity}

We use five agree/disagree questions to evaluate LinkedIn users' perceptions in terms of social and professional identity. The results are presented in Table 2 and Figure 2. The statement for Question 1 is as follows: "I try to present myself in a favorable way on LinkedIn." As for accounting majors, $86 \%$ of the respondents agree with the statement, while about $4 \%$ disagree with the statement, and about $10 \%$ of respondents neither agree nor disagree with the statement. As for other business majors, about $91 \%$ of the respondents agree with the statement, while about $2 \%$ disagree with the statement, and about $7 \%$ of the respondents neither agree nor disagree with the statement. The statement for Question 2 is as follows: "LinkedIn helps me to present my best sides to others." As for accounting majors, about $75 \%$ of the respondents agree with the statement, while only $7 \%$ of the respondents disagree with the statement, and about $18 \%$ of the respondents are neutral with the statement. As for other business majors, about $83 \%$ of the respondents agree with the statement, while none of the respondents disagree with the statement and about $17 \%$ of the respondents are neutral with the statement.

The statement for Question 3 is as follows: "I often update or edit my profile information on LinkedIn." As for accounting majors, about $42 \%$ of the LinkedIn users agree with the statement, while only $33 \%$ of respondents disagree with the statement, and about $25 \%$ of respondents are neutral with the statement. As for other business majors, about $44 \%$ of the LinkedIn users agree with the statement, while $38 \%$ of the respondents disagree with the statement and about $18 \%$ of the respondents are neutral with the statement. The statement for Question 4 is as follows: "I would like to post my professional photo." As for accounting majors, about $85 \%$ of the LinkedIn users agree with the statement, while only $11 \%$ of respondents disagree with the statement, and about $4 \%$ of respondents are neutral with the statement. As for other business majors, about $87 \%$ of the respondents agree with the statement, while $4 \%$ of the respondents disagree with the statement and about $9 \%$ of respondents are neutral with the statement. 
Table 2. Results of H1: Social and Professional Identity

\begin{tabular}{|c|c|c|c|c|c|c|c|}
\hline Question 1 & \multicolumn{7}{|c|}{ I try to present myself in a favorable way on LinkedIn. } \\
\hline Question 2 & \multicolumn{7}{|c|}{ LinkedIn helps me to present my best sides to others. } \\
\hline Question 3 & \multicolumn{7}{|c|}{ I often update or edit my profile information on LinkedIn. } \\
\hline Question 4 & \multicolumn{7}{|c|}{ I would like to post my professional photo. } \\
\hline Question 5 & \multicolumn{7}{|c|}{ I would like to list my college/university as the place where I am studying/studied. } \\
\hline Major & Question & $\begin{array}{l}\text { Strongly } \\
\text { Disagree }\end{array}$ & Disagree & $\begin{array}{l}\text { Neither } \\
\text { Agree } \\
\text { Nor } \\
\text { Disagre }\end{array}$ & Agree & $\begin{array}{l}\text { Strongly } \\
\text { Agree }\end{array}$ & Total \\
\hline \multirow{5}{*}{$\begin{array}{l}\text { Accounting } \\
\text { Major }\end{array}$} & Question 1 & $2.1 \%$ & $2.1 \%$ & $10.4 \%$ & $20.8 \%$ & $64.6 \%$ & $100.0 \%$ \\
\hline & Question 2 & $2.3 \%$ & $4.7 \%$ & $18.6 \%$ & $32.6 \%$ & $41.9 \%$ & $100.0 \%$ \\
\hline & Question 3 & $16.7 \%$ & $16.7 \%$ & $25.0 \%$ & $27.1 \%$ & $14.6 \%$ & $100.0 \%$ \\
\hline & Question 4 & $4.2 \%$ & $6.3 \%$ & $4.2 \%$ & $37.5 \%$ & $47.9 \%$ & $100.0 \%$ \\
\hline & Question 5 & $2.1 \%$ & $4.2 \%$ & $4.2 \%$ & $33.3 \%$ & $56.3 \%$ & $100.0 \%$ \\
\hline \multirow{5}{*}{$\begin{array}{l}\text { Non- } \\
\text { Accounting } \\
\text { Major }\end{array}$} & Question 1 & $0.0 \%$ & $2.2 \%$ & $6.7 \%$ & $35.6 \%$ & $55.6 \%$ & $100.0 \%$ \\
\hline & Question 2 & $0.0 \%$ & $0.0 \%$ & $17.1 \%$ & $48.8 \%$ & $34.1 \%$ & $100.0 \%$ \\
\hline & Question 3 & $8.9 \%$ & $28.9 \%$ & $17.8 \%$ & $35.6 \%$ & $8.9 \%$ & $100.0 \%$ \\
\hline & Question 4 & $0.0 \%$ & $4.4 \%$ & $8.9 \%$ & $40.0 \%$ & $46.7 \%$ & $100.0 \%$ \\
\hline & Question 5 & $0.0 \%$ & $0.0 \%$ & $6.7 \%$ & $42.2 \%$ & $51.1 \%$ & $100.0 \%$ \\
\hline
\end{tabular}

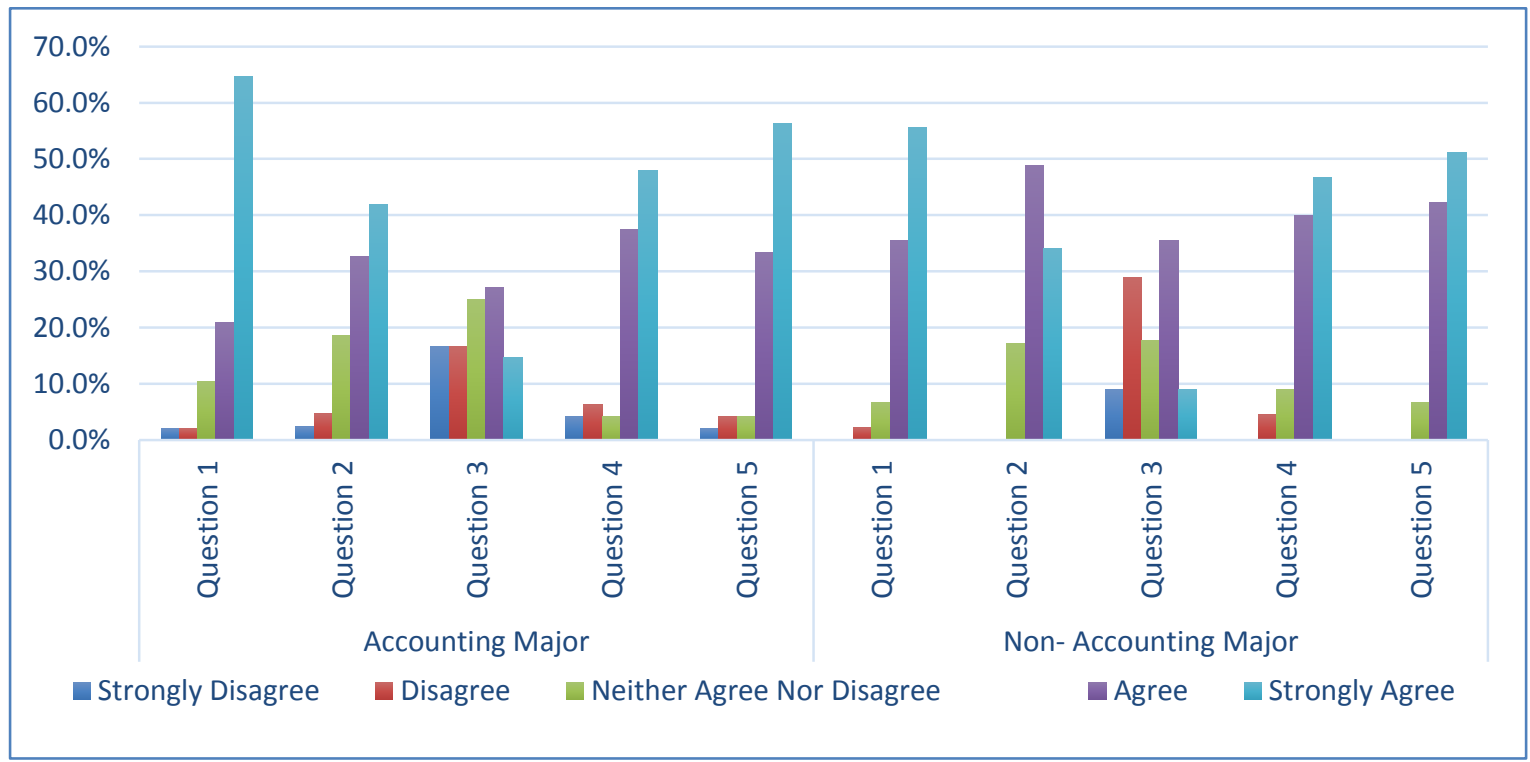

Figure 2. Social and Professional Identity

The statement for Question 5 is as follows: "I would like to list my college/university as the place where I am studying/studied." As for accounting majors, about $90 \%$ of the LinkedIn users agree with the statement, while only $6 \%$ of respondents disagree with the statement, and about $4 \%$ of respondents are neutral with the statement. As for other business majors, about $93 \%$ of the LinkedIn users agree with the statement, while none of the respondents disagree with the statement, and about $7 \%$ of respondents are neutral with the statement. The analysis of the answers to the 
above questions supports $H 1$ that accounting and other business students perceive LinkedIn as a positive social capital to construct their social and professional identity. On LinkedIn, both HBCU accounting and other business students present themselves in a favorable way, post their professional photo, and list their college/university as the place where they are studying/studied. They perceive that LinkedIn helps them to present their best sides to others. However, they don't update or edit their profile information on LinkedIn very often. The results of the chi-squared test don't provide any evidence for significant differences in all the questions between the above two groups.

The analysis of the answers to the above questions supports $\mathrm{Hl}$ that accounting and other business students perceive LinkedIn as a positive social capital to construct their social and professional identity. On LinkedIn, both HBCU accounting and other business students present themselves in a favorable way, post their professional photo, and list their college/university as the place where they are studying/studied. They perceive that LinkedIn helps them to present their best sides to others. However, they don't update or edit their profile information on LinkedIn very often. The results of the chi-squared test don't provide any evidence for significant differences in all the questions between the above two groups.

These findings reveal the perceived benefits by respondents via LinkedIn usage. The findings show that the majority of the respondents are receptive to the needs of each other. The results agree with the theories of social identity and intrinsic motivation discussed earlier. The respondents do not update their profiles often and remain inactive in interactions with others because the students' major focus is on their academic work. Damnjanovlé, Matovic, Kostic, \& Okanovié (2012) point out that the reasons for activating a profile and frequently updating it on LinkedIn usually depends on the participants' occupation and discipline. This has also been explained by the prior literature with respect to users' misconceptions. Florenthal (2015) found that light users and nonusers of LinkedIn seem to have the same misconceptions that a presence on LinkedIn should be developed or/initiated only after graduation. Hall (2013) stated that the light users or nonusers of LinkedIn are not realizing the importance of networking until after they graduate and enter the job market.

\subsection{H2: Future Career Development}

Six agree/disagree questions are presented in Table 3 and Figure 3 to evaluate LinkedIn users' perceptions of future career development. The statement for Question 1 is as follows: "LinkedIn helps me to expand my network." As for accounting majors, over $80 \%$ of the respondents agree with the statement, while about $5 \%$ disagree with the statement, and about $15 \%$ of respondents neither agree nor disagree with the statement. As for business non-accounting majors, about $96 \%$ of the respondents agree with the statement, while about $4 \%$ disagree with the statement, and no respondents neither agree nor disagree or strongly disagree with the statement. The statement for Question 2 is as follows: "Other LinkedIn members are open and receptive to the needs of each other." As for accounting majors, about $52 \%$ of the respondents agree with the statement, while only $11 \%$ of respondents disagree with the statement, and about $37 \%$ of respondents are neutral with the statement. As for business non-accounting majors, about $71 \%$ of the respondents agree with the statement, while $4 \%$ of the respondents disagree with the statement, and about $25 \%$ of respondents are neutral with the statement.

The statement for Question 3 is as follows: "I would like to respond to the invitations in a timely way." As for accounting majors, about $71 \%$ percent of the respondents agree with the statement, while about $13 \%$ disagree with the statement, and about $16 \%$ of respondents neither agree nor disagree with the statement. As for business non-accounting majors, about $82 \%$ of the respondents agree with the statement, while about $11 \%$ disagree with the statement, and about 7\% of respondents neither agree nor disagree with the statement. The statement for Question 4 is as follows: "I would like to get up-to-date information as for accounting or business communities via LinkedIn." As for accounting majors, about $38 \%$ of the respondents agree with the statement, while about $46 \%$ of respondents disagree with the statement, and about $16 \%$ of respondents are neutral with the statement. As for business non-accounting majors, about $62 \%$ of the respondents agree with the statement, while $24 \%$ of the respondents disagree with the statement and about $14 \%$ of respondents are neutral with the statement.

The statement for Question 5 is as follows: "At LinkedIn I find some information about job and career." As for accounting majors, about $77 \%$ percent of the respondents agree with the statement, while about $11 \%$ disagree with the statement, and about $12 \%$ of respondents neither agree nor disagree with the statement. As for business non-accounting majors, about $89 \%$ of the respondents agree with the statement, while about $2 \%$ disagree with the statement, and about $9 \%$ of respondents neither agree nor disagree with the statement. 
Table 3. Future Career Development

\begin{tabular}{|c|c|c|c|c|c|c|c|}
\hline Question 1 & \multicolumn{7}{|c|}{ LinkedIn helps me to expand my network. } \\
\hline Question 2 & \multicolumn{7}{|c|}{ Other LinkedIn members are open and receptive to the needs of each other. } \\
\hline Question 3 & \multicolumn{7}{|c|}{ I would like to respond to the invitations in a timely way. } \\
\hline Question 4 & \multicolumn{7}{|c|}{$\begin{array}{l}\text { I would like to get up-to-date information as for accounting or business communities via } \\
\text { LinkedIn. }\end{array}$} \\
\hline Question 5 & \multicolumn{7}{|c|}{ At LinkedIn I find some information about job and career. } \\
\hline Question 6 & \multicolumn{7}{|c|}{$\begin{array}{l}\text { Using a business college's alumni group, I can network with alumni to find internship or } \\
\text { career opportunities. }\end{array}$} \\
\hline Major & Question & $\begin{array}{l}\text { Strongly } \\
\text { Disagree }\end{array}$ & Disagree & $\begin{array}{l}\text { Neither Agree } \\
\text { Nor Disagree }\end{array}$ & Agree & $\begin{array}{l}\text { Strongly } \\
\text { Agree }\end{array}$ & Total \\
\hline \multirow{6}{*}{$\begin{array}{l}\text { Accounting } \\
\text { Major }\end{array}$} & Question 1 & $4.2 \%$ & $0.0 \%$ & $14.6 \%$ & $50.0 \%$ & $31.3 \%$ & $100.0 \%$ \\
\hline & Question 2 & $6.3 \%$ & $4.2 \%$ & $37.5 \%$ & $33.3 \%$ & $18.8 \%$ & $100.0 \%$ \\
\hline & Question 3 & $6.3 \%$ & $6.3 \%$ & $16.7 \%$ & $37.5 \%$ & $33.3 \%$ & $100.0 \%$ \\
\hline & Question 4 & $25.0 \%$ & $20.8 \%$ & $16.7 \%$ & $18.8 \%$ & $18.8 \%$ & $100.0 \%$ \\
\hline & Question 5 & $0.0 \%$ & $10.6 \%$ & $12.8 \%$ & $36.2 \%$ & $40.4 \%$ & $100.0 \%$ \\
\hline & Question 6 & $4.2 \%$ & $2.1 \%$ & $20.8 \%$ & $41.7 \%$ & $31.3 \%$ & $100.0 \%$ \\
\hline \multirow{6}{*}{$\begin{array}{l}\text { Non-Account } \\
\text { ing Major }\end{array}$} & Question 1 & $0.0 \%$ & $4.4 \%$ & $0.0 \%$ & $46.7 \%$ & $48.9 \%$ & $100.0 \%$ \\
\hline & Question 2 & $0.0 \%$ & $4.4 \%$ & $24.4 \%$ & $55.6 \%$ & $15.6 \%$ & $100.0 \%$ \\
\hline & Question 3 & $2.2 \%$ & $8.9 \%$ & $6.7 \%$ & $57.8 \%$ & $24.4 \%$ & $100.0 \%$ \\
\hline & Question 4 & $11.1 \%$ & $13.3 \%$ & $13.3 \%$ & $44.4 \%$ & $17.8 \%$ & $100.0 \%$ \\
\hline & Question 5 & $2.2 \%$ & $0.0 \%$ & $8.9 \%$ & $53.3 \%$ & $35.6 \%$ & $100.0 \%$ \\
\hline & Question 6 & $0.0 \%$ & $2.2 \%$ & $8.9 \%$ & $57.8 \%$ & $31.1 \%$ & $100.0 \%$ \\
\hline
\end{tabular}

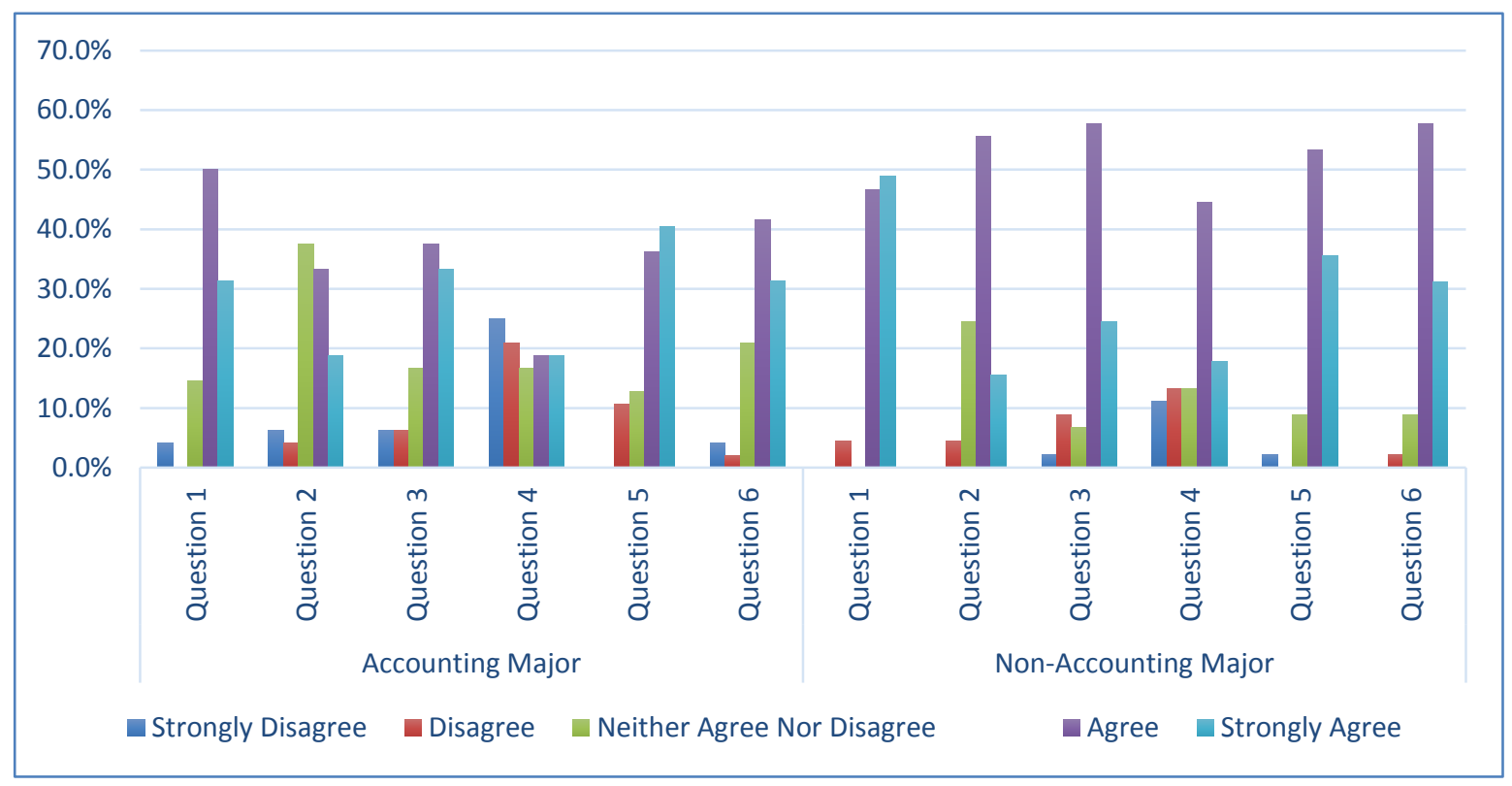

Figure 3. Future Career Development 
The statement for Question 6 is as follows: "Using a business college's alumni group, I can network with alumni to find internship or career opportunities." As for accounting majors, about $73 \%$ percent of the respondents agree with the statement, while about $6 \%$ disagree with the statement, and about $21 \%$ of respondents neither agree nor disagree with the statement. As for business non-accounting majors, about $89 \%$ of the respondents agree with the statement, while about $2 \%$ disagree with the statement, and about $9 \%$ of respondents neither agree nor disagree with the statement.

The Chi-squared test does not show any significant difference in the distributions of Question 1, Question 3 and Question 6 between the above two groups. However, the results indicate that there are significant differences in the distribution of statement $2\left(\chi^{2}=12.440, p=0.014\right)$, a marginal significant difference in question $4\left(\chi^{2}=8.311, p=\right.$ $0.081)$, and a marginal significant difference in question $5\left(\chi^{2}=7.821, \mathrm{p}=0.099\right)$, respectively.

The above results support $H 2$ that accounting and other business students perceive LinkedIn as a positive benefit to their future career development. Both accounting and other business students perceive that LinkedIn helps them to expand their network. Using a business college's alumni group, they can network with alumni to find internships or career opportunities. Therefore, they would like to respond to the invitations in a timely way. However, compared with other business students, accounting students agree that other LinkedIn members are less open and receptive to the needs of each other. Thus, they are less likely to find some information about job and career and get up-to-date information.

\section{4 H3: Interactive Learning Resources}

Five agree/disagree questions are presented in Table 4 and Figure 4 to evaluate LinkedIn users' perceptions with respect to interactive learning Resources. The statement for Question 1 is as follows: "LinkedIn allows me to save time when I want to share information and ideas with my connections." As for accounting majors, about $63 \%$ of the respondents agree with the statement, while about $14 \%$ disagree with the statement, and about $23 \%$ of respondents neither agree nor disagree with the statement. As for other business majors, about $69 \%$ of the respondents agree with the statement, while about $7 \%$ disagree with the statement, and about $24 \%$ of respondents neither agree nor disagree with the statement. The statement for Question 2 is as follows: "I do not participate in discussions, just watch communities for updates." As for accounting majors, about $53 \%$ of the respondents agree with the statement, while about $17 \%$ disagree with the statement, and about $30 \%$ of respondents neither agree nor disagree with the statement. As for other business majors, about $56 \%$ of the respondents agree with the statement, while about $18 \%$ disagree with the statement, and about $26 \%$ of respondents neither agree nor disagree with the statement.

The statement for Question 3 is as follows: "I'm an active participant in terms of comments and discussion topics sharing." As for accounting majors, about $13 \%$ of the respondents agree with the statement, while about $56 \%$ disagree with the statement, and about $31 \%$ of respondents neither agree nor disagree with the statement. As for other business majors, about $22 \%$ of the respondents agree with the statement, while about $58 \%$ disagree with the statement, and about $20 \%$ of respondents neither agree nor disagree with the statement.

The statement for Question 4 is as follows: "I trust information obtained via professional communities on LinkedIn." As for accounting majors, about $60 \%$ of the respondents agree with the statement, while about $17 \%$ disagree with the statement, and about $23 \%$ of respondents neither agree nor disagree with the statement. As for other business majors, about $87 \%$ of the respondents agree with the statement, while about $6 \%$ disagree with the statement, and about $7 \%$ of respondents neither agree nor disagree with the statement. The statement for Question 5 is as follows: "Social networking sites such as LinkedIn is more distracting than helpful to students for academic work." As for accounting majors, about $46 \%$ of the respondents agree with the statement, while about $25 \%$ disagree with the statement, and about $29 \%$ of respondents neither agree nor disagree with the statement. As for other business majors, about $27 \%$ of the respondents agree with the statement, while about $64 \%$ disagree with the statement, and about $9 \%$ of respondents neither agree nor disagree with the statement.

As to the perception of interactive learning resources of LinkedIn, the chi-squared test does not present any significant difference in the distributions of Question 1, Question 2 and Question 3 between the above two groups. However, the results indicate that there are significant differences in the distribution of question $4\left(\chi^{2}=15.903, p=0.003\right)$ and question $5\left(\chi^{2}=9.558, \mathrm{p}=0.049\right)$, respectively.

The results support $H 3$ that accounting and other business students believe LinkedIn is a positive interactive learning resource in the university settings. Both accounting and other business students perceive that LinkedIn can save them time when they want to share information and ideas with their connections. However, most of the time they just watch communities for updates instead of actively participating in comments and discussions. Compared with other business 
students, accounting students put less trust in the information obtained via professional communities on LinkedIn. Accounting students agree that LinkedIn is more distracting than helpful to students for academic work.

Table 4. Interactive Learning Resources

Question 1 LinkedIn allows me to save time when I want to share information and ideas with my connections.

Question 2 I do not participate in discussions, just watch communities for updates.

Question $3 \quad$ I'm an active participant in terms of comments and discussion topics starting.

Question $4 \quad$ I trust information obtained via professional communities on LinkedIn.

Question 5 Social networking sites such as LinkedIn is more distracting than helpful to students for academic work

\begin{tabular}{|c|c|c|c|c|c|c|c|}
\hline Major & Question & $\begin{array}{l}\text { Strongly } \\
\text { Disagree }\end{array}$ & Disagree & $\begin{array}{l}\text { Neither } \\
\text { Agree Nor } \\
\text { Disagree }\end{array}$ & Agree & $\begin{array}{l}\text { Strongly } \\
\text { Agree }\end{array}$ & Total \\
\hline \multirow{5}{*}{$\begin{array}{l}\text { Accounting } \\
\text { Major }\end{array}$} & Question 1 & $6.3 \%$ & $8.3 \%$ & $22.9 \%$ & $41.7 \%$ & $20.8 \%$ & $100.0 \%$ \\
\hline & Question 2 & $4.3 \%$ & $12.8 \%$ & $29.8 \%$ & $31.9 \%$ & $21.3 \%$ & $100.0 \%$ \\
\hline & Question 3 & $16.7 \%$ & $39.6 \%$ & $31.3 \%$ & $2.1 \%$ & $10.4 \%$ & $100.0 \%$ \\
\hline & Question 4 & $6.3 \%$ & $10.4 \%$ & $22.9 \%$ & $39.6 \%$ & $20.8 \%$ & $100.0 \%$ \\
\hline & Question 5 & $10.4 \%$ & $14.6 \%$ & $29.2 \%$ & $29.2 \%$ & $16.7 \%$ & $100.0 \%$ \\
\hline \multirow{5}{*}{$\begin{array}{l}\text { Non-Accounti } \\
\text { ng Major }\end{array}$} & Question 1 & $0.0 \%$ & $6.7 \%$ & $24.4 \%$ & $48.9 \%$ & $20.0 \%$ & $100.0 \%$ \\
\hline & Question 2 & $8.9 \%$ & $8.9 \%$ & $26.7 \%$ & $40.0 \%$ & $15.6 \%$ & $100.0 \%$ \\
\hline & Question 3 & $17.8 \%$ & $40.0 \%$ & $20.0 \%$ & $13.3 \%$ & $8.9 \%$ & $100.0 \%$ \\
\hline & Question 4 & $0.0 \%$ & $6.7 \%$ & $6.6 \%$ & $60.0 \%$ & $26.7 \%$ & $100.0 \%$ \\
\hline & Question 5 & $20.0 \%$ & $44.4 \%$ & $8.9 \%$ & $15.6 \%$ & $11.1 \%$ & $100.0 \%$ \\
\hline
\end{tabular}

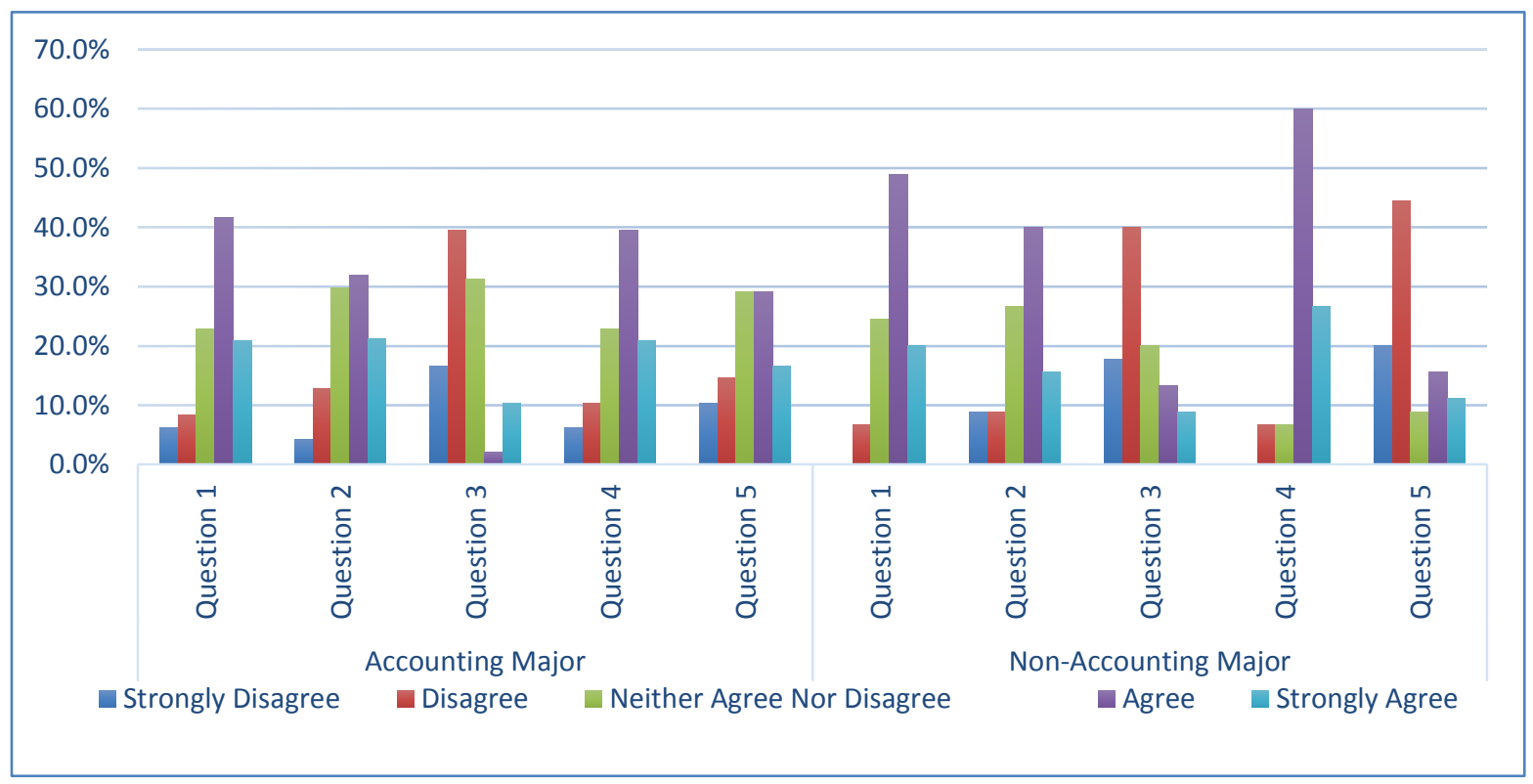

Figure 4. Interactive Learning Resources 
In summary, the findings in our study support all the proposed hypotheses. First, the findings suggest that accounting students and other business students at HBCUs perceive that LinkedIn serves as a platform to enable them to express their identity and build self-image. Second, LinkedIn also enables them to get connected with their professional peers for career development opportunities. Finally, respondents trust the information they obtain via LinkedIn. However, as compared with other business students, accounting students are less likely to find helpful up-to-date information about jobs and careers. They consider LinkedIn more distracting than helpful to students for academic work, which leads to less trust in the information obtained via professional communities on LinkedIn.

\section{Conclusion}

The current study uses accounting students and other business students at HBCUs as the participants to investigate their perceptions of LinkedIn usage and the impacts of LinkedIn on their self-presentation and establishment of social identity, career development, and interactive learning process. As little research evaluates the use of LinkedIn in minority serving institutions such as HBCUs, our study aims to assess accounting students and other business students' perceptions and usage of LinkedIn in HBCU settings.

Based on social capital theory and motivation theory, the results show that the accounting and other business students at HBCUs trust the information on LinkedIn and would be willing to respond and share information with the communities on LinkedIn. They are willing to present themselves favorably on the profiles of LinkedIn. They view LinkedIn as a helpful source of career and job information as well as a platform to connect with their alumni for future career development. Compared with other business students, accounting students show less trust in the information obtained from the professional network on LinkedIn and are less likely to obtain the beneficial career information due to the less open and less receptive connections on LinkedIn.

Our study has two contributions to the literature on social network sites. First, our study is one of the few academic studies which examine the impact of the professional social networking site LinkedIn on college business students. Specifically, our study focuses on the perceptions of accounting and other business students at HBCUs, who are underrepresented groups. Moreover, our study contributes to the literature of social networking sites by investigating the users' perceptions of LinkedIn in terms of social identity and self-presentation, professional development, and interactive learning resource.

Our study has strong implications for future accounting and business professionals, accounting and business educators at higher institutions, specifically shedding some insights for the students and educators at HBCUs. The accounting and other business students may benefit from our findings to build personal image on LinkedIn and connect with their peers, alumni, and other professionals in their area to guide their professional development. They may also effectively use LinkedIn as a tool to enhance their engagement in interactive learning processes. As for educators at HBCUs, they can utilize the findings in our study to guide their students on how to build their profile, how to network with others on LinkedIn, and how to build their professional brand for their career development.

However, this study has some limitations. First, the study collects data only from accounting and business students at three HBCUs. For the purpose of generalizability, future studies can collect data from different majors at different HBCU schools to evaluate their perceptions and usage of LinkedIn. Also, future studies may compare different majors' perceptions and usage of LinkedIn, e.g. business majors and computer science majors. Second, the study only focuses on the professional social networking site LinkedIn. Therefore, another direction of future study can compare respondents' perceptions and usage of LinkedIn with other professional network such as XING, a European social networking sites for professionals. Finally, since HBCU students are an underrepresented group, it is promising to explore how HBCU students' perceptions and usage of LinkedIn can be applied in college learning environment. This application assists students with being aware of the importance of LinkedIn in today's world of social networking.

\section{References}

Adler, P.S. \& Kwon, S. (2002). Social capital: Prospects for a new concept. Academy of Management Review, 27(1), 17-40. https://doi.org/10.2307/4134367

Alexander, J. (2013). Online Identity. Sales \& Service Excellence Essentials, 13(1), 4-4.

Beach, C. (2016). Incorporating Social Media into Career Planning. Healthcare Executive, 31(1), 58-61.

Boyd, D. \& Heer, J. (2006). Profiles as Conversation: Networked Identity Performance on Friendster. Proceedings of the 39th Annual Hawaii International Conference on System Sciences (HICSS'06). https://doi.org/10.1109/HICSS.2006.394 
Burt, R. (1997). The contingent value of social capital. Administrative Science Quarterly, 42, 339-365. https://doi.org/10.1016/B978-0-7506-7222-1.50014-3

Buzzetto-More, N. (2012). Social Networking in Undergraduate Education. Interdisciplinary Journal of Information, Knowledge \& Management, 7, 63-90. https://doi.org/10.28945/1578

Chiang, J. K. \& Suen, H. (2015). Self-presentation and hiring recommendations in online communities: Lessons from LinkedIn. Computers in Human Behavior, 48, 516-524. https://doi.org/10.1016/j.chb.2015.02.017

Chu, C., \& Meulemans, Y. (2008). The problems and potential of MySpace and Facebook usage in academic libraries. Internet Reference Services Quarterly, 13(1), 69-85. https://doi.org/10.1300/J136v13n01_04

Coleman, J. S. (1988). Social capital in the creation of human capital. American Journal of Sociology, 94(Supplement), S95-S120. https://doi.org/10.1086/228943

DamnjanovIéS, V., Matovic, V., Kostic, K. S. \& Okanovié, M. (2012).The Role of the LinkedIn Social Media in Building the Personal Image. Management Journal for Theory and Practice Management, 65, 15-23.

Davis, F.D. (1989). Perceived Usefulness, Perceived Ease of Use, and User Acceptance of information Technology. MIS Quarterly, 13, 319-340. https://doi.org/10.2307/249008

Davis, F. D., Bagozzi, R. P., \& Warshaw, P. R. (1992). Extrinsic and intrinsic motivation to use computers in the workplace. Journal of Applied Social Psychology, 22(14), 1111-1132. https://doi.org/10.1111/j.1559-1816.1992.tb00945.x

Dijck, J. V. 2013. 'You have one identity': performing the self on Facebook and LinkedIn. Media, Culture \& Society, 35(2). https://doi.org/10.1177/0163443712468605

Dwyer, C., Hiltz, S.R. \& Passerini, K. (2007). Trust and Privacy in Social Networking Sites. Proceedings of the Thirteenth Americas Conference on Information Systems, Keystone. [Online] Available: http://csis.pace.edu/ dwyer/research/DwyerAMCIS2007.pdf.

EbizMBA. (2018). Top 15 Most popular social networking sites. [Online] Available: http://www.ebizmba.com/articles/social-networking-websites.

Ellison, N. B., Steinfield, C \& Lampe, C. (2007). The benefits of Facebook "Friends:" social capital and college Students' Use of Online Social Network Sites. Journal of Computer-Mediated Communication, 12(4), 1143-1168. https://doi.org/10.1111/j.1083-6101.2007.00367.x

Ellison, N. B., Steinfield, C., \& Lampe, C. (2011). Connection strategies: Social capital implications of Facebook-enabled communication practices. New Media \& Society, 13(6), 873-892. https://doi.org/10.1177/1461444810385389

Emarketer. College students still spend most time with Facebook. Available at: https://www.emarketer.com/Article/College-Students-Still-Spend-Most-Social-Time-with-Facebook/1012955.

Escobedo, J. (2017). Singapore's young entrepreneurs share how LinkedIn has helped grow their business. Available at:

https://www.forbes.com/sites/joeescobedo/2017/11/05/singapores-young-entrepreneurs-share-how-linkedin-ha s-helped-grow-their-business/\#52133e2a269a.

Florenthal, B. (2015). Applying uses and gratifications theory to students' LinkedIn usage. Young Consumers, 16(1), 17-35. https://doi.org/10.1108/YC-12-2013-00416

Foss, Jenny (2012). Your LinkedIn Intervention: 5 Changes You Must Make. Forbes.

Gabre, H. G., \& Kumar, G. (2012). The effects of perceived stress and facebook on accounting students' academic performance. Accounting \& Finance Research, 1(2), 87-100. https://doi.org/10.5430/afr.v1n2p87

Gray, R., Ellison, N.B. \& Vitak, J. (2013). Who wants to know? Question-asking and answering practices among Facebook users. In Proceedings of the 2013 conference on computer supported cooperative work, San Antonio, TX, 23-27 February, pp. 1213-1224. New York: ACM.

Hall, B. (2013). Why Aren't College Students Using LinkedIn To Find Jobs? [Online] Available: http://readwrite.com/2013/04/23/why-arentcollege-students-using-linkedin-to-find-jobs.

HBCU Colleges (Historically Black Colleges and Universities). HBCU Schools Offering Accounting Programs - 2018 Ranking. Available at: https://hbcu-colleges.com/accounting. 
Hannon, K. (2015). Stand out on social media. Money, 44(8), 27-28.

Heifetz, J. (2015). Professional Transitions: How to use your LinkedIn profile to power a career transition. Harvard Busines Review. Available at: https://hbr.org/2015/05/how-to-use-your-linkedin-profile-to-power-a-career-transition.

Herbold, J. \& Douma, B. (2013). Students' use of social media for job seeking. CPA Journal, 83(4), 68-71.

Hew, K. F. (2011). Students' and teachers' use of Facebook. Computers in Human Behavior, 27, $662-676$. https://doi.org/10.1016/j.chb.2010.11.020

Igbaria, M., Parasuraman, S., \& Baroudi, J. J. (1996). A Motivational Model of Microcomputer Usage. Journal of Management Information Systems, 13(1), 127-143. https://doi.org/10.1080/07421222.1996.11518115

Irwin, C., Ball, L., \& Desbrow, B. (2012). Students' perceptions of using Facebook as an interactive learning resource at university. Australasian Journal of Educational Technology, 28(7), 1221-1232. https://doi.org/10.14742/ajet.798

Johnson, J. (2011). Growing your accounting firm with LinkedIn. Accounting Today. [Online] Available: https://www.accountingtoday.com/news/growing-your-accounting-firm-with-linkedin.

Johnston, K., Tanner, M., Lalla, N., \& Kawalski, D. (2013). Social capital: the benefit of Facebook 'friends'. Behavior \& Information Technology, 32(1), 24-36. https://doi.org/10.1080/0144929X.2010.550063

Junco, R. (2011). The need for student social media policies. Educause Review, 46(1), 60-61.

Kwon, O., \& Wen, Y. (2010). An empirical study of the factors affecting social network service Use. Computers in Human Behavior, 26, 254-263. https://doi.org/10.1016/j.chb.2009.04.011

Lin, N. (1999). Building a Network theory of Social Capital. Connections, 22, 28-51.

Lin, C. P. \& Bhattacherjee, A. (2008). Elucidating individual intention to use interactive information technologies: the role of network externalities. International Journal of Electronic Commerce, 13(1), 85-108. https://doi.org/10.2753/JEC1086-4415130103.

Lin, K. Y., \& Lu, H. P. (2011). Why people use social networking sites: An empirical study integrating network externalities and motivation theory. Computers in Human Behavior, 27(3), 1152-1161. https://doi.org/10.1016/j.chb.2010.12.009

LinkedIn. [Online] Available: http://www.linkedin.com/about-us.

Liu, C.Y. \& Yu, C.P. (2013). Can Facebook use induce well-being? Cyber Psychology, Behavior and Social Networking, 16(9), 674-678. http://doi.org/10.1089/cyber.2012.0301

Lu, H.P. \& Yang, Y.W. (2014). Toward an understanding of the behavioral intention to use a social networking site: An extension of task-technology fit to social-technology fit. Computers in Human Behavior, 34, 323-332. https://doi.org/10.1016/j.chb.2013.10.020

Mathiyalakan, S, White, S. D., \& Brusa, J. O. (2016). Facebook use among African American and Hispanic students: An exploratory investigation of perceived academic impact. Journal of International Technology and Information Management, 25(2), 101-118. Available at: http://scholarworks.lib.csusb.edu/jitim/vol25/iss2/6.

Mazer, J. P., Murphy, R. E., \& Simonds, C.S. (2007). I'll see you on "Facebook": The effects of computer-mediated teacher self-disclosure on student motivation, affective learning, and classroom climate. Communication Education, 56(1), 1-17. https://doi.org/10.1080/03634520601009710

McCorkle, D. E., \& McCorkle, Y. L. (2012). Using LinkedIn in the marketing classroom: exploratory insights and recommendations for teaching social media/ networking. Marketing Education Review, 22, 157-166. https://doi.org/10.2753/MER1052-8008220205

Mendez, J. P., Le, K., \& Cruz, J. D. (2014). Integrating Facebook in the classroom: Pedagogical dilemmas. Journal of Instructional Pedagogies, 13, 1-10.

Morris, M.R., Teevan, J., \& K. Panovich, K. (2010). What do people ask their social networks, and why? A survey study of status message Q\&A behavior. Proceedings of the SIGCHI conference on human factors in computing systems, Atlanta, GA, 10-15 April, pp. 1739-1748. New York: ACM.

Nahapiet, J., \& Ghoshal, S. (1998). Social capital, intellectual capital, and the organizational advantage. Academy of management review, 23(2), 242-266. https://doi.org/10.5465/amr.1998.533225 
National Association of Black Accountants (NABA). [Online] Available: https://www.nabainc.org/about_us.

Nielsen. (2014). State of the media: The social media report 2012. [Online] Available: http://www.nielsen.com/us/en/newswire/2012/social-media-report-2012-socialmedia-comes-of-age.html.

Parez, M. E. (2013). Linked Into a Job?: the Ethical Considerations of Recruiting Through LinkedIn. Management, [Online] Available: http://docs.rwu.edu/management_theses/.

Pempek, T. A., Yermolayeva, Y. A., \& Calvert, S. (2009). College students' social networking experiences on Facebook. Journal of Applied Developmental Psychology, 30(3), 227-238. https://doi.org/10.1016/j.appdev.2008.12.010

Reiss, S. (2012). Intrinsic and Extrinsic Motivation. Teaching of Psychology, 39(2), 152-156. https://doi.org/10.1177/0098628312437704

Roldan, M. M., Sutanonpaiboon, J., \& Burkhard, R. (2017). Professional and personal social networking and enhancement of social capital in young adults. Journal of International Technology \& Information Management, 26(3), 46-80.

Ryan, R. M., \& Deci, E. L. (2000). Self-determination theory and the facilitation of intrinsic motivation, social development, and well-being. American Psychologist, 55, 68-78. https://doi.org/10.1037/0003-066X.55.1.68

Singson, M. \& Sunkara, R. (2012). Post-Graduate student's acceptance of social networking sites: a survey. Asia Pacific Journal of Library and Information Science, 2(1), 28-49. [Online] Available: SSRN: https://ssrn.com/abstract=2124792.

Steinfield, C., Ellison, N. B., \& Lampe, C. (2008). Social capital, self-esteem, and use of online social network sites: A longitudinal analysis. Journal of Applied Developmental Psychology, 29(6), 434-445. https://doi.org/10.1016/j.appdev.2008.07.002

Stone, G., Fiedler, B., \& Kandunias, C. (2014). Harnessing Facebook for student engagement in accounting education: Guiding principles for accounting students and educators. Accounting Education, 23(4), 295-321. https://doi.org/10.1080/09639284.2014.908730

Utz, S. (2016). Is LinkedIn making you more successful? The informational benefits derived from public social media. New Media \& Society, 18(11), 2685-2702. https://doi.org/10.1177/1461444815604143

Vitak, J. \& Ellison, N.B. (2012). There's a network out there you might as well tap: exploring the benefits of and barriers to exchanging informational and support-based resources on Facebook. New Media \& Society, 15(2), 243-259. https://doi.org/10.1177/1461444812451566 